\title{
SHORT REPORT: CD4 T CELL ACTIVATION AS A PREDICTOR FOR TREATMENT FAILURE IN UGANDANS WITH PLASMODIUM FALCIPARUM MALARIA
}

\author{
MARK P. EGGENA, HEIDI HOPKINS, BANSON BARUGAHARE, MARTIN OKELLO, FRANCIS SSALI, \\ PETER MUGYENYI, PHILIP J. ROSENTHAL, HUYEN CAO, AND GRANT DORSEY* \\ Department of Medicine, San Francisco General Hospital, University of California, San Francisco, California; Joint Clinical Research \\ Centre, Kampala, Uganda; California Department of Health Services, Richmond, California
}

\begin{abstract}
Host immunity plays an important role in response to antimalarial therapy but is poorly understood. To test whether $\mathrm{T}$ cell activation is a risk factor for antimalarial treatment failure, we studied $\mathrm{CD} 4^{+}$and $\mathrm{CD}^{+} \mathrm{T}$ cell activation in 31 human immunodeficiency virus-negative Ugandan patients 5-37 years of age who were treated for uncomplicated Plasmodium falciparum malaria. Increased CD4 ${ }^{+} \mathrm{T}$ cell activation, as indicated by co-expression of HLA-DR and CD38, was an independent risk factor for treatment failure (hazard ratio $=2.45$, 95\% confidence interval $=1.02-5.89, P=0.05)$ in multivariate analysis controlling for age, baseline temperature, and pre-treatment parasite density. The results provide insight into the role of cellular immunity in response to antimalarial therapy and underscore the need to investigate the mechanisms behind immune activation.
\end{abstract}

Plasmodium falciparum malaria is a major source of morbidity and mortality, especially in sub-Saharan Africa. The complexity of the parasite life cycle and high diversity of strains has limited progress in understanding the immunopathogenesis of this disease. The presence of $P$. falciparumspecific antibodies have previously been associated with improved responses to antimalarial treatment. ${ }^{1-3}$ The role of $\mathrm{T}$ cell responses in malaria has been less well defined, although specific cytokine profiles have been associated with protection against severe disease. ${ }^{4-7}$ Expression of CD38 and HLA$\mathrm{DR}$ on $\mathrm{CD}^{+}$and $\mathrm{CD} 8^{+} \mathrm{T}$ cells is thought to provide a general assessment of the extent to which a pathogen activates the immune system, but this expression does not necessarily correlate with the effectiveness of the $\mathrm{T}$ cell response in eliminating the pathogen. These activation parameters have been studied most comprehensively in human immunodeficiency virus (HIV) infection, where they have been shown to be very strong independent predictors of disease progression and death. ${ }^{8,9}$ Increased expression of these markers has also been associated with Mycobacterium tuberculosis and Epstein-Barr virus infections: ${ }^{10,11}$ however, its prognostic value has not been reported. In these diseases, the mechanism of immune activation is unclear and may represent both specific and nonspecific bystander activation. ${ }^{12,13}$

Few studies of immune activation in malaria have been reported, and to our knowledge, none have investigated this parameter in relation to treatment outcome. Available studies agree that malaria is associated with increased activation of the immune system. ${ }^{14,15}$ Independent predictors of treatment failure in uncomplicated $P$. falciparum malaria confirmed in multiple studies include young age, high temperature at presentation, and high pre-treatment parasite density. ${ }^{16}$ We hypothesized that high temperature might be a surrogate marker for immune activation and investigated whether this parameter is associated with treatment outcome.

Our investigation was part of a larger study conducted between December 2003 and August 2004 at Mulago Hospital in Kampala, Uganda to assess the dynamics of parasite clear-

\footnotetext{
* Address correspondence to Grant Dorsey, San Francisco General Hospital, 1001 Potrero, Building 30, Room 408, San Francisco, CA 94110. E-mail: grantd@itsa.ucsf.edu
}

ance after standard antimalarial therapy. Patients were enrolled in the main study if they were $\geq 6$ months of age, had uncomplicated $P$. falciparum malaria with a parasite density less than $400,000 / \mu \mathrm{L}$, and no evidence of any concomitant febrile illness. Convenience sampling was used to identify a subgroup of patients $\geq 5$ years of age (to ensure adequate blood volumes) for participation in the immunology studies. After the clinical study, patient identifiers were delinked and HIV testing was conducted with two parallel enzyme-linked immunosorbent assays followed by Western blots for discordant results. Patients infected with HIV were excluded from the immunologic studies.

All patients were given directly observed therapy with chloroquine $(25 \mathrm{mg} / \mathrm{kg}$ over a three-day period) plus sulfadoxinepyrimethamine $(25 \mathrm{mg} / \mathrm{kg}$ of sulfadoxine and $1.25 \mathrm{mg} / \mathrm{kg}$ of pyrimethamine given as a single dose), the recommended first-line therapy for uncomplicated malaria in Uganda at the time of the study. Patients were followed for 42 days and treatment outcomes classified according to the World Health Organization classification system as early treatment failure (ETF), late clinical failure (LCF), late parasitologic failure (LPF), or adequate clinical and parasitologic response (ACPR). ${ }^{17}$ For all patients requiring repeat therapy (ETF, LCF, and LPF), molecular genotyping was conducted to distinguish recrudescence (true treatment failure) from new infection, as previously described. ${ }^{18}$ Treatment failure was defined as all ETFs and any LTF or LPF due to recrudescence. The study was reviewed and approved by the Institutional Review Boards of the University of California, San Francisco and Makerere University (Kampala, Uganda). All study participants provided written informed consent.

Immediately before the initiation of therapy, blood was drawn and peripheral blood mononuclear cells (PBMCs) were isolated by Ficoll-Hypaque gradient centrifugation. Freshly isolated PBMCs were analyzed for $\mathrm{CD}^{+}$and $\mathrm{CD}^{+} \mathrm{T}$ cell activation using the FACScalibur system (Becton Dickinson, Franklin Lakes, NJ) as previously described. ${ }^{19}$ Associations between independent variables and levels of immune activation were made using multivariate linear regression. The risk of treatment failure was estimated using the KaplanMeier product limit formula with censoring for new infections. Associations between exposure variables and treatment failure were estimated using the Cox proportional hazard 
model. All $P$ values were two-sided, and a value $\leq 0.05$ was considered statistically significant.

A total of 230 patients completed the main study, of which 146 were $\geq 5$ years of age. Immunologic studies were performed on 33 patients. Two patients were excluded because of HIV infection, giving a total sample size of 31 . The average age of participants in the immunology study was 12.6 years (range $=5-37$ ), and 52\% were female. The average tympanic temperature at presentation was $37.6^{\circ} \mathrm{C}$ (range $=35.3-$ $40.9^{\circ} \mathrm{C}$ ). The geometric mean parasite density was 27,897 asexual parasite $/ \mu \mathrm{L}$ (range $=1,560-229,120$ ). Compared with patients $\geq 5$ years of age not included in the immunologic sub-study, patients included in the immunologic sub-study did not differ with respect to age, temperature, or parasite density ( $P>0.05$ for all comparisons). Fifty-five percent of the patients required repeat therapy after 42 days; however, after adjustment by genotyping to exclude new infections, the risk of treatment failure was $29 \%$.

To investigate whether immune activation is associated with clinical predictors of treatment failure, we performed multivariate linear regression (Table 1). Activated $\mathrm{T}$ cells were defined as the percentage of $\mathrm{CD} 4^{+}$or $\mathrm{CD} 8^{+} \mathrm{T}$ cells that co-express CD38 and HLA-DR. Because CD38 is known to be an early $\mathrm{T}$ cell differentiation marker, an inverse association with age was anticipated and controlled for in all analyses. Interestingly, $\mathrm{CD}^{+}$activation, but not $\mathrm{CD} 8^{+} \mathrm{T}$ cell activation, was strongly associated with temperature at presentation $(P=0.005$ and $P=0.86$, respectively). This association was independent of age and parasite density.

We next investigated whether $\mathrm{T}$ cell activation was a predictor for treatment failure in a multivariate model controlling for age, temperature, and parasite density. Decreasing age and increasing baseline temperature were associated with an increased risk of treatment failure, as expected, although these associations did not reach statistical significance (baseline model) (Table 2). The association of age and temperature with treatment outcome reached statistical significance in the larger cohort of patients $\geq 5$ years and older $(n=146)$ from which the immunologic sub-study was sampled (hazard ratio $[\mathrm{HR}]=0.58, P=0.001$ and $\mathrm{HR}=1.46, P=0.004$, respectively) suggesting that the lack of significance in the immunology study was due to small sample size. When immune activation was added to the model including age, temperature, and parasite density, a significant association was observed between $\mathrm{CD} 4^{+} \mathrm{T}$ cell activation and treatment failure $(\mathrm{HR}=2.45, P=0.05)$. Moreover, addition of $\mathrm{CD}^{+} \mathrm{T}$ cell activation to the multivariate models caused the trend towards association between high temperature and treatment

TABLE 1

Associations between clinical factors and immune activation

\begin{tabular}{|c|c|c|}
\hline Dependent variable* & $\begin{array}{l}\text { Independent } \\
\text { variable } \dagger\end{array}$ & $\begin{array}{c}\text { Multivariate } \\
\text { coefficient } \nleftarrow(P)\end{array}$ \\
\hline \multirow[t]{2}{*}{$\mathrm{CD}^{+} \mathrm{T}$ cell activation } & Temperature $\S$ & $2.00(0.005)$ \\
\hline & Parasite densityII & $-1.26(0.13)$ \\
\hline \multirow[t]{2}{*}{$\mathrm{CD}^{+} \mathrm{T}$ cell activation } & Temperature & $-0.30(0.86)$ \\
\hline & Parasite density & $-1.14(0.60)$ \\
\hline
\end{tabular}

TABLE 2

Associations between immune activation and antimalarial treatment failure

\begin{tabular}{|c|c|c|c|}
\hline Model & Covariates & $\mathrm{HR}(95 \% \mathrm{CI})^{*}$ & $P$ \\
\hline \multirow[t]{3}{*}{ Baseline } & Age $\dagger$ & $0.66(0.38-1.12)$ & 0.12 \\
\hline & Temperature & $1.37(0.78-2.40)$ & \\
\hline & Parasite density§ & $0.75(0.39-1.42)$ & 0.37 \\
\hline \multirow[t]{4}{*}{$\mathrm{CD}^{+}{ }^{\mathrm{HLA}}-\mathrm{DR}^{+} \mathrm{CD} 38^{+}$} & Age $\dagger$ & $0.62(0.32-1.23)$ & 0.17 \\
\hline & Temperature $\ddagger$ & $0.98(0.50-1.92)$ & \\
\hline & Parasite density§ & $0.91(0.43-1.93)$ & \\
\hline & Immune activation $\mathbb{I}$ & $2.45(1.02-5.89)$ & \\
\hline \multirow[t]{4}{*}{$\mathrm{CD}^{+}{ }^{+} \mathrm{HLA}-\mathrm{DR}^{+} \mathrm{CD} 38^{+}$} & Age $\dagger$ & $0.56(0.31-1.04)$ & 0.07 \\
\hline & Temperature $\ddagger$ & $1.49(0.84-2.64)$ & 0.17 \\
\hline & Parasite density§ & $0.61(0.28-1.33)$ & $0.22-2$ \\
\hline & Immune activation $\mathbb{I}$ & $1.17(0.85-1.59)$ & 0.33 \\
\hline
\end{tabular}

$* \mathrm{HR}=$ hazard ratio using Cox proportional hazards model. $\mathrm{CI}=$ confidence interval Bold values are statistically significant with $P \leq 0.05$.

$\dagger$ Per five year increase.

$\$$ Per $1^{\circ} \mathrm{C}$ increase.

natural $\log$

II Per $5 \%$ increase.

failure to disappear $(\mathrm{HR}=0.98, P=0.95)$. Finally, the associations between $\mathrm{CD}^{+} \mathrm{T}$ cell activation and treatment failure were consistent when temperature was removed from the models $(\mathrm{HR}=2.41, P=0.02)$. The $\mathrm{CD}^{+} \mathrm{T}$ cell activation was not significantly associated with treatment outcome.

Clinical response to antimalarial therapy involves a complex interaction between parasites, drugs, and host response. Although the immune system is believed to play a critical role in the successful treatment of malaria, few immune correlates have been shown to be predictors of treatment success or failure. We found that $\mathrm{CD}^{+} \mathrm{T}$ cell activation was strongly associated with temperature at presentation. Furthermore, in multivariate analyses, $\mathrm{CD} 4^{+} \mathrm{T}$ cell activation, but not temperature, was an independent predictor of treatment failure after antimalarial therapy. These findings suggest that previous associations between higher baseline temperature and treatment failure may have been confounded by $\mathrm{CD} 4^{+} \mathrm{T}$ cell activation. Our findings suggest that $\mathrm{CD}^{+} \mathrm{T}$ cell activation rather than fever plays a causal role in response to antimalarial therapy.

Why should increased $\mathrm{CD} 4^{+} \mathrm{T}$ cell activation, presumably a sign of a robust immune response, be a risk factor for treatment failure? One hypothesis is that our immunophenotype for immune activation represents a dysfunctional immune response. Alternatively, a highly stimulated immune system might result from infection with a parasite strain against which the host has limited prior immunity. Pre-existing antibodies might improve treatment outcome $\mathrm{e}^{1-3}$ and limit the degree of $\mathrm{T}$ cell activation, such that only novel strains, which are most likely to evade immune responses and contribute to drug failure, elicit heightened T cell activation. Previous studies have suggested a direct immune correlate between $\mathrm{T}$ cellmediated interferon- $\gamma$ and tumor necrosis factor- $\alpha$ production and natural immunity against $P$. falciparum..$^{4-7}$ It is also interesting to speculate why we did not observe correlation of treatment failure with $\mathrm{CD}^{+} \mathrm{T}$ cell activation in our study, which may imply a larger role for $\mathrm{CD}^{+}$cells rather than $\mathrm{CD}^{+} \mathrm{T}$ cells in immune responses to malaria.

The primary limitation of our study is small sample size for our immunology sub-study because of cost and logistic constraints of performing the assays on site in Uganda. The lack of statistically significant associations between treatment out- 
come and age or temperature is likely the result of the small sample size because associations between outcome and these parameters have been independently confirmed in six previous studies in Kampala ${ }^{16}$ and in the larger cohort from which the immunologic sub-study was sampled. The fact that we were able to observe a significant association between $\mathrm{T}$ cell activation and response to antimalarial therapy with such a limited sample size reflects the strength of this association.

Immune activation is predictive of HIV disease progression in antiretroviral-naive populations and has been associated with lower $\mathrm{CD}^{+} \mathrm{T}$ cell increases after initiation of antiretroviral treatment. ${ }^{8,9,20,21}$ To our knowledge, this is the first assessment of immune activation as a predictor for treatment failure in malaria. Our findings underscore the need to investigate the mechanisms behind immune activation. The development of a malaria vaccine will be facilitated by understanding this and other immune correlates of protection and treatment outcome. Additional studies of relationships between immune activation and treatment outcomes, including longitudinal studies, are needed to better delineate the importance of these parameters.

Received June 4, 2005. Accepted for publication September 6, 2005. Acknowledgments: We thank the Makerere University-University of California, San Francisco Kampala staff (Basaliza M. Karakire, Regina Nakafeero, Maxwell B. Kilama, Marx Dongo, William Musoke, Bridget Nzarubara, Anne Gasasira, Denise Njama-Meya, Gertrude Kilama, Christopher Bongole, Mary Kasango, Sara Kibirango, Kenneth Mwebaze and Erika Leemann) for their assistance. We also sincerely thank all study patients for participating in this investigation.

Financial support: This work was supported by National Institutes of Health (NIH) grants AI43754, AI054366, and AI052142, and the Fogarty International Center/NIH (grant TW00007).

Disclosure: None of the authors have any commercial or other associations that might pose a conflict of interest.

Authors' addresses: Mark P. Eggena, Heidi Hopkins, Philip J. Rosenthal, and Grant Dorsey, Department of Medicine, San Francisco General Hospital, University of California, San Francisco, CA 94110, Telephone: 415-206-4680, Fax: 415-648-8425, E-mail: grantd@ itsa.ucsf.edu. Banson Barugahare, Martin Okello, Francis Ssali, and Peter Mugyenyi, Joint Clinical Research Centre, Kampala, Uganda. Huyen Cao, California Department of Health Services, Richmond, CA 94801.

\section{REFERENCES}

1. Mawili-Mboumba DP, Borrmann S, Cavanagh DR, McBride JS, Matsiegui PB, Missinou MA, Kremsner PG, Ntoumi F, 2003. Antibody responses to Plasmodium falciparum merozoite surface protein-1 and efficacy of amodiaquine in Gabonese children with P. falciparum malaria. J Infect Dis 187: 1137-1141.

2. Mayxay M, Chotivanich K, Pukrittayakamee S, Newton P, Looareesuwan S, White NJ, 2001. Contribution of humoral immunity to the therapeutic response in falciparum malaria. $A m J$ Trop Med Hyg 65: 918-923.

3. Robert V, Roeffen W, Brasseur P, Aribot G, Verhave JP, Roussilhon C, 2000. Anti-NANP antibody and treatment efficacy in patients with acute uncomplicated falciparum malaria attacks. Parasite Immunol 22: 589-593.

4. Ramharter M, Kremsner PG, Willheim M, Winkler H, Graninger W, Winkler S, 2004. Plasmodium falciparum-specific interleukin-2 and tumor necrosis factor-alpha expressing-T cells are associated with resistance to reinfection and severe malaria in healthy African children. Eur Cytokine Netw 15: 189-196.

5. Winkler S, Willheim M, Baier K, Graninger W, Kremsner PG, 1999. Frequency of cytokine-producing CD4-CD8- peripheral blood mononuclear cells in patients with Plasmodium falciparum malaria. Eur Cytokine Netw 10: 155-160.

6. Winkler S, Willheim M, Baier K, Schmid D, Aichelburg A, Graninger W, Kremsner PG, 1998. Reciprocal regulation of Th1- and Th2-cytokine-producing $\mathrm{T}$ cells during clearance of parasitemia in Plasmodium falciparum malaria. Infect Immun 66: 6040-6044.

7. Winkler S, Willheim M, Baier K, Schmid D, Aichelburg A, Graninger W, Kremsner PG, 1999. Frequency of cytokineproducing $\mathrm{T}$ cells in patients of different age groups with Plasmodium falciparum malaria. J Infect Dis 179: 209-216.

8. Giorgi JV, Hultin LE, McKeating JA, Johnson TD, Owens B, Jacobson LP, Shih R, Lewis J, Wiley DJ, Phair JP, Wolinsky SM, Detels R, 1999. Shorter survival in advanced human immunodeficiency virus type 1 infection is more closely associated with $\mathrm{T}$ lymphocyte activation than with plasma virus burden or virus chemokine coreceptor usage. J Infect Dis 179: 859-870.

9. Hazenberg MD, Otto SA, van Benthem BH, Roos MT, Coutinho RA, Lange JM, Hamann D, Prins M, Miedema F, 2003. Persistent immune activation in HIV-1 infection is associated with progression to AIDS. AIDS 17: 1881-1888.

10. Rodrigues DS, Medeiros EA, Weckx LY, Bonnez W, Salomao R, Kallas EG, 2002. Immunophenotypic characterization of peripheral T lymphocytes in Mycobacterium tuberculosis infection and disease. Clin Exp Immunol 128: 149-154.

11. Zidovec Lepej S, Vince A, Rakusic S, Dakovic Rode O, Sonicki Z, Jeren T, 2003. Center for Disease Control (CDC) flow cytometry panel for human immunodeficiency virus infection allows recognition of infectious mononucleosis caused by Epstein-Barr virus or cytomegalovirus. Croat Med J 44: 702-706.

12. Cohen Stuart JW, Hazebergh MD, Hamann D, Otto SA, Borleffs JC, Miedema F, Boucher CA, de Boer RJ, 2000. The dominant source of CD4+ and CD8+ T-cell activation in HIV infection is antigenic stimulation. J Acquir Immune Defic Syndr 25: 203211.

13. Grossman Z, Paul WE, 2000. The impact of HIV on naive T-cell homeostasis. Nat Med 6: 976-977.

14. Kemp K, Akanmori BD, Adabayeri V, Goka BQ, Kurtzhals JA, Behr C, Hviid L, 2002. Cytokine production and apoptosis among T cells from patients under treatment for Plasmodium falciparum malaria. Clin Exp Immunol 127: 151-157.

15. Worku S, Bjorkman A, Troye-Blomberg M, Jemaneh L, Farnert A, Christensson B, 1997. Lymphocyte activation and subset redistribution in the peripheral blood in acute malaria illness: distinct gammadelta+ $\mathrm{T}$ cell patterns in Plasmodium falciparum and $P$. vivax infections. Clin Exp Immunol 108: 34-41.

16. Dorsey G, Gasasira AF, Machekano R, Kamya MR, Staedke SG Hubbard A, 2004. The impact of age, temperature, and parasite density on treatment outcomes from antimalarial clinical trials in Kampala, Uganda. Am J Trop Med Hyg 71: 531-536.

17. World Health Organization, 2003. Assessment and monitoring of antimalarial drug efficacy for the treatment of uncomplicated falciparum malaria. Available from http://www.emro.who.int/ $\mathrm{rbm} /$ publications/protocolwho.pdf.

18. Cattamanchi A, Kyabayinze D, Hubbard A, Rosenthal PJ, Dorsey G, 2003. Distinguishing recrudescence from reinfection in a longitudinal antimalarial drug efficacy study: comparison of results based on genotyping of msp-1, msp-2, and glurp. Am J Trop Med Hyg 68: 133-139.

19. Eggena MP, Barugahare B, Okello M, Mutyala S, Jones N, Ma Y, Kityo C, Mugyenyi P, Cao H, 2005. T cell activation in HIVseropositive Ugandans: differential associations with viral load, CD4+ T cell depletion, and coinfection. J Infect Dis 191: 694-701.

20. Hunt PW, Deeks SG, Rodriguez B, Valdez H, Shade SB, Abrams DI, Kitahata MM, Krone M, Neilands TB, Brand RJ, Lederman MM, Martin JN, 2003. Continued CD4 cell count increases in HIV-infected adults experiencing 4 years of viral suppression on antiretroviral therapy. AIDS 17: 1907-1915.

21. Sousa AE, Carneiro J, Meier-Schellersheim M, Grossman Z, Victorino RM, 2002. CD4 T cell depletion is linked directly to immune activation in the pathogenesis of HIV-1 and HIV-2 but only indirectly to the viral load. J Immunol 169: 3400-3406. 